\title{
PEMBUATAN PROFIL PRODUK UNTUK PEMASARAN BARANG DAN JASA BAGI UP2K-PKK KELURAHAN PRAWIRODIRJAN GONDOMANAN YOGYAKARTA
}

\author{
Harliyus Agustian ${ }^{1}$, Asih Pujiastuti², Astika Ayuningtyas ${ }^{3}$, Anton Setiawan \\ Honggowibowo ${ }^{4}$, Yuliani Indrianingsih ${ }^{5}$ \\ $\mathbf{1 , 2 , 3 , 4 , 5}$ Program Studi Teknik Informatika \\ Sekolah Tinggi Teknologi Adisutjipto \\ Jl. Janti, Blok R, Lanud Adisutjipto Yogyakarta \\ Email : ${ }^{1}$ harliyus@stta.ac.id, ${ }^{2}$ asihpuji@ stta.ac.id, ${ }^{3}$ astika@stta.ac.id, \\ 4anton_s_h@yahoo.com, 5 yulistta@gmail.com
}

\begin{abstract}
Family Income Improvement Company (UP2K) - Fostering Family Welfare $(P K K)$ is a form of activity aimed at improving the family economy. The UP2K-PKK in Prawirodirjan brings together 27 players in the goods and services trade. It is possible to increase the marketing of UP $2 K-P K K$ participants' products in Prawirodirjan by creating product profiles as a means of offering or promoting. To create a product profile, you can create product photos using a smartphone. Taking pictures to take pictures of products requires photography and photo editing techniques using a smartphone. Improved photographic techniques and photo editing skills of UP $2 K-P K K$ participants can be achieved through training support provided by lecturers from the Computer Science Department of the Yogyakarta Adisucipto College of Technology as a form of community service activity.
\end{abstract}

Keywords: Profile Products, Photographic Techniques, Smartphones, UP2K-PKK

\begin{abstract}
Abstrak
Usaha Peningkatan Pendapatan Keluarga (UP2K) - Pembinaan Kesejahteraan Keluarga (PKK) merupakan salah satu bentuk kegiatan untuk meningkatkan perekonomian keluarga. UP2K-PKK di Prawirodirjan menaungi 28 pelaku usaha yang bergerak di bidang produk barang dan jasa. Peningkatan pemasaran produk peserta UP2K-PKK di Prawirodirjan dapat dilakukan dengan cara pembuatan profil produk sebagai sarana penawaran atau promosi. Pembuatan profil produk dapat dilakukakan dengan pembuatan foto produk yang dapat dilakukan dengan menggunakan smartphone. Pengambilan foto guna pembuatan foto produk memerlukan ketrampilan teknik photografi dan editing foto menggunakan smartphone. Peningkatan ketrampilan teknik photografi dan editing foto para peserta UP2K-PKK dapat dilakukan dengan pendampingan pelatihan oleh dosen Departemen Informatika Sekolah Tinggi Teknologi Adisutjipto Yogyakarta sebagai bentuk kegiatan pengabdian kepada masyarakat.
\end{abstract}

Kata Kunci: Profil Produk, Teknik Photografi, Smartphone, UP2K-PKK 


\section{Latar Belakang}

Usaha ekonomi keluarga merupakan kegiatan usaha yang dilakukan oleh keluarga dengan tujuan meningkatkan pendapatan keluarga dalam rangka mewujudkan kesejahteraan keluarga[1]. Usaha Peningkatan Pendapatan Keluarga (UP2K) Pembinaan Kesejahteraan Keluarga (PKK) merupakan salah satu bentuk kegiatan yang selenggarakan oleh kelurahan Prawirodirjan untuk meningkatkan perekonomian keluarga. UP2K-PKK merupakan segala kegiatan ekonomi yang diusahakan oleh keluarga, baik, secara perorangan maupun kelompok. Modalnya bersumber dari swadaya masyarakat, bantuan pemerintah, bantuan luar negeri, swasta, serta sumber lain yang sah dan tidak mengikat.

UP2K-PKK Prawirodirjan menaungi 27 pelaku usaha ekonomi keluarga. Usaha yang dijalankan bergerak di bidang produk dan jasa, diantaranya; kerajinan, makanan, pemotongan ayam, jasa penitipan anak, laundry, barber shop, pijat, dan lain sebagainya. Pemasaran merupakan salah satu faktor penting dalam menjalankan proses usaha. Sampai saat ini, strategi pemasaran yang dilakukan oleh para pelaku UP2K-PKK Prawirodirjan adalah pemasaran secara sederhana yaitu pemasaran produk dengan pengenalan dan penjualan produk melalui relasi di lingkungan pelaku usaha.

Profil produk dibuat dengan tujuan untuk memperkenalkan produk dan meningkatkan citra baik pelaku UP2K-PKK Prawirodirjan kepada masyarakat luas [2]. Teknik photografi yang tepat dibutuhkan dalam pengambilan gambar produk guna pembuatan profil produk yang baik. Selain dengan gambar atau foto produk, profil produk dapat dibuat menggunakan video mini tentang produk yang ditawarkan. Profil produk yang baik diharapkan mampu meningkatkan penjualan produk UP2K-PKK Prawirodirjan.

Berdasarkan analisis situasi dan permasalahan mitra di atas, kegiatan pengabdian ini menjadi solusi kebutuhan para pelaku UP2K-PKK Prawirodirjan [3], melihat kondisi yang terjadi, perlu adanya pelatihan khusus yang menyediakan ruang untuk pelaku UP2K-PKK Prawirodirjan mempraktekkan pembuatan profil produk untuk dipasarkan melalui online. Praktek ini bersifat mandiri, artinya setiap pelaku UP2K-PKK memegang satu komputer dengan harapan pemahaman dan pengujian materi lebih maksimal. Selain itu, memberi pengalaman pada pelaku UP2K-PKK dalam mengimplementasikan dan mengembangkan profil produk untuk mendukung proses pemasaran produk melalui online. Kegiatan pengabdian pada masyarakat dititikberatkan dalam bentuk pelatihan teknik pengambilan foto dan video beserta cara mengeditnya. Pengabdian ini merupakan kesinambungan dari pengabdian yang sudah dilakukan sebelumnya [4][5][6] [7].

\section{Masalah}

Ada dua permasalahan yang dihadapi oleh UP2K PKK Kelurahan Prawirodirjan yang diselesaikan dengan melakukan pendampingan, yaitu :

1. Kurangnya kemampuan pelaku UP2K-PKK Prawirodirjan dalam membuat profil produk yang menarik untuk dipasarkan melalui online, permasalahan ini diselesaikan dengan pendampingan pembuatan profil produk untuk pemasaran produk.

2. Terbatasnya ketrampilan pelaku UP2K-PKK Prawirodirjan dalam pengambilan foto produk yang menarik untuk dipasarkan melalui online, permasalahan ini diselesaikan dengan pelatihan teknik pengambilan foto produk untuk kebutuhan pemasaran. 


\section{Metode}

Kegiatan yang dilaksanakan berupa pendampingan dalam bentuk pembuatan profil produk untuk meningkatan pemasaran produk melalui online termasuk pelatihan teknik pengambilan foto produk. Materi pelatihan disesuaikan dengan kebutuhan para pelaku UP2K-PKK Prawirodirjan yang menunjang pada proses pemasaran produk. Peningkatan jangkauan pemasaran dan volume penjualan dapat dilakukan dengan internet marketing atau sosial media. Pemasaran menggunakan sosial media menjadi lebih efektif dan efisien [8]. Sosial media yang sering digunakan untuk pemasaran salah satunya adalah Instagram (Ig). Instagram dapat didefinisikan sebagai sebuah aplikasi berbagi foto yang memungkinkan pengguna mengambil foto, menerapkan filter digital , dan membagikannya ke berbagai layanan jejaring sosial, termasuk milik instagram sendiri[9] [10].

Pada tahapan pertama, tim pelaksanan pengabdian melakukan beberapa kegiatan, diantaranya koordinasi para pelaksana untuk menyiapkan tempat dan perlengkapan guna mendukung terlaksananya pelatihan, kemudian tim pelaksana melakukan koordinasi dengan para peserta yaitu pelaku UP2K-PKK Prawirodirjan untuk penyebaran undangan pelaksanaan pendampingan. Langkah berikutnya mempersiapkan modul pelatihan untuk pembuatan profil produk untuk meningkatan pemasaran produk melalui online dengan rincian materi seperti yang terlihat pada Tabel 1.

Tabel 1. Topik Materi Pada Modul Pelatihan

\begin{tabular}{c|l}
\hline No. & \multicolumn{1}{|c}{ Topik } \\
\hline \hline 1. & Pengenalan pemasaran produk melalui online: Profil Produk \\
2. & Teknik Pengambilan Foto \\
3. & Editing Foto \\
4. & Teknik PengambilanVideo \\
5. & Editing Video \\
\hline
\end{tabular}

Untuk mengukur tingkat keberhasilan kegiatan pendampingan pelatihan pembuatan profil produk untuk meningkatan pemasaran produk melalui online bagi pelaku UP2K-PKK Prawirodirjan ini, peserta diberikan pengarahan pentingnya membuat profil produk dalam pemasaran online, kemudian peserta mendapat pelatihan tentang bagaimana teknik pengambilan foto dan video produk dan dilanjutkan dengan pelatihan cara mengedit foto dan video. Pada tahap akhir, peserta diberikan tugas untuk membuat profil produk masing-masing. Tahap ini dimaksudkan untuk mengetahui kemampuan para pelaku UP2K-PKK dalam memanfaatkan aplikasi yang diajarkan untuk membuat profil produk.

\section{Hasil dan Pembahasan}

Pendampingan pelatihan pembuatan profil produk dan jasa dengan memanfaatkan kamera handphone untuk mengambil gambar atau foto produk dan jasa untuk digunakan dalam memasarkan produk dimedia online dengan menampilkan foto profil produk dan jasa bagi pelaku UP2K PKK Kelurahan Prawirodirjan. Pendampingan pembuatan teknik pengambilan foto dengan memanfaatkan kamera handphone untuk membuat profil produk dan jasa dilaksanakan di Laboratorium K3 Sekolah Tinggi Teknologi Adisutjipto (STTA) Yogyakarta pada bulan Desember 2019. Pendampingan dilaksanakan selama sembilan jam, sesuai waktu yang ditargetkan. Peserta kegiatan berjumlah dua puluh delapan pelaku usaha. 


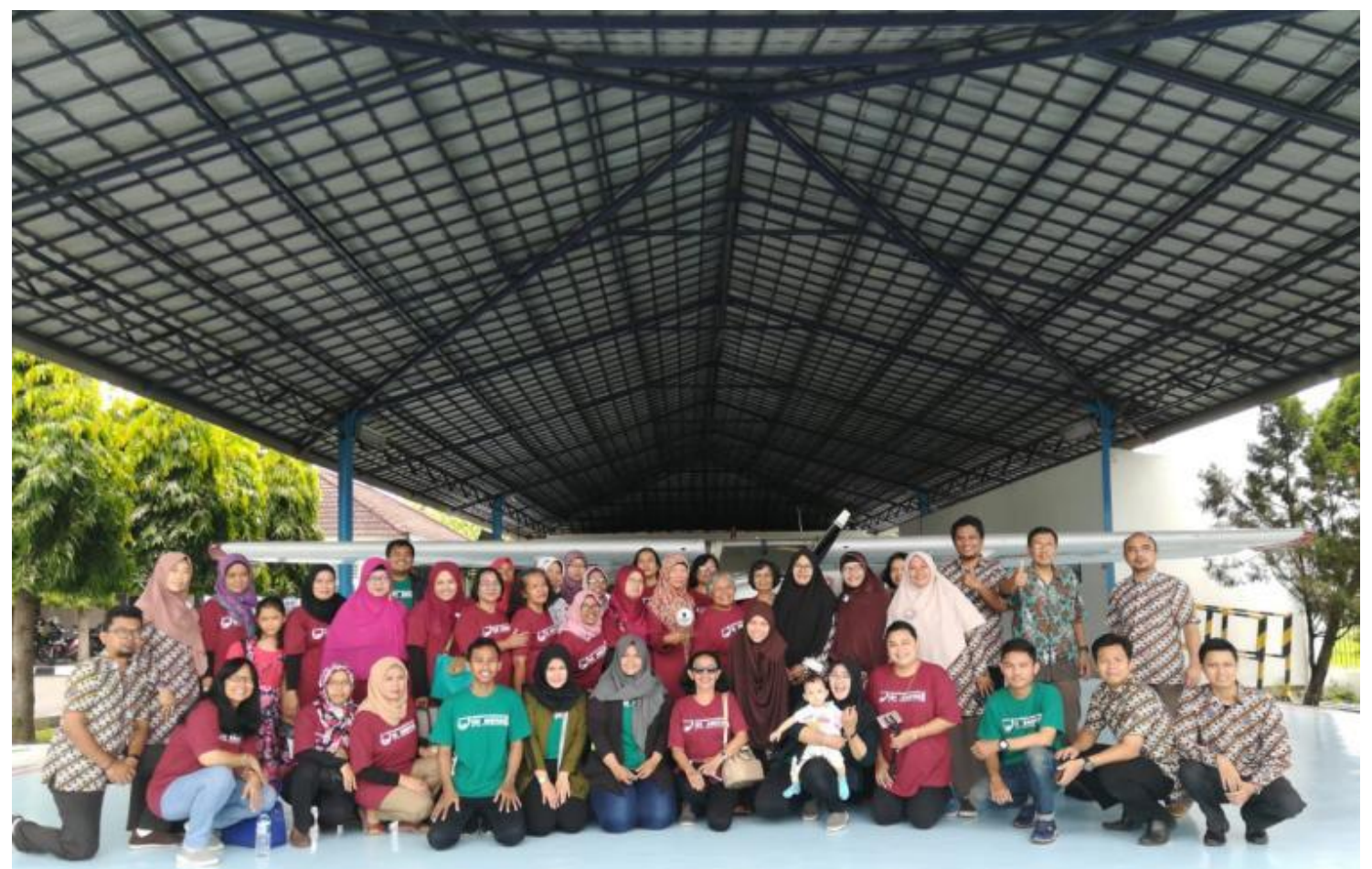

Gambar 1. Tim Pelaksana dan Peserta Pengabdian Kepada Masyarakat

Jumlah peserta pengabdian secara keseluruhan adalah dua puluh delapan orang yang berasal dari UP2K PKK Kelurahan Prawirodirjan Yogyakarta. Kedua puluh delapan orang tersebut merupakan pelaku usaha rumahan yang memproduksi produk dan jasa untuk dipasarkan. Kegiatan tersebut didampingi Lurah Prawirodirjan, Ketua LPMK dan Ketua PK-KK kelurahan Prawirodirjan seperti di Gambar 2.

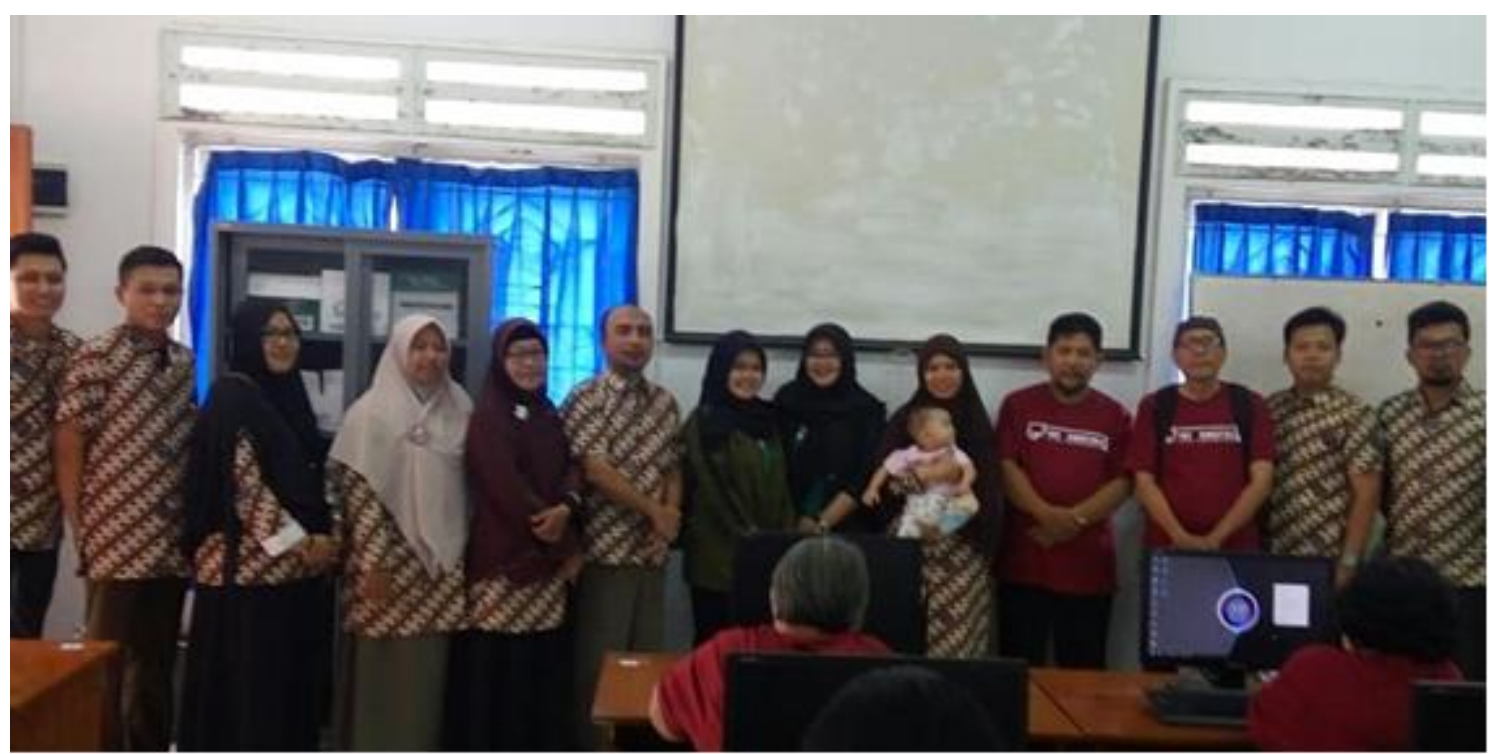

Gambar 2. Tim Pelaksana beserta Bapak Lurah dan Ketua LPMK Kelurahan Prawirodirjan 
Kegiatan diawali dengan pemberian sambutan oleh Kepala Departemen Informatika STTA Yogyakarta dan di hari terakhir pendampingan ditutup dengan pemberian kenang-kenangan dari Departemen Informatika STTA kepada UP2K PKK Kelurahan Prawirodirjan (Gambar 3 dan 4).

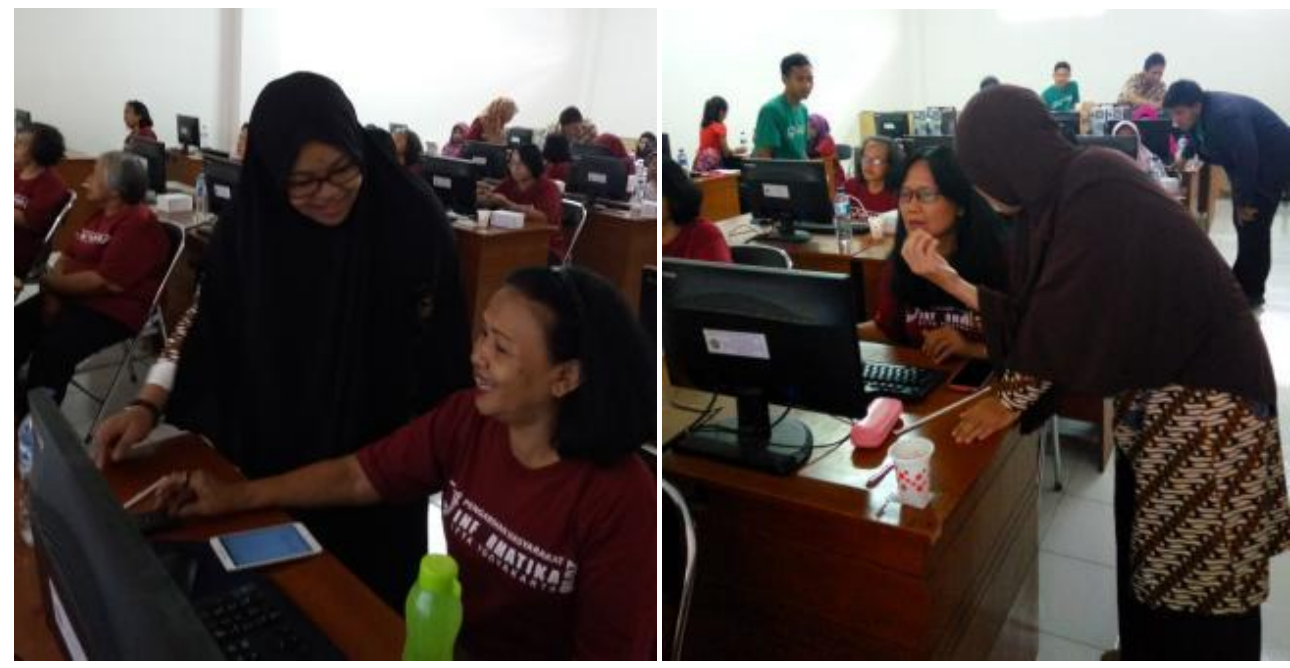

Gambar 3. Kegiatan Pendampingan kepada UP2K PKK Kelurahan Prawirodirjan

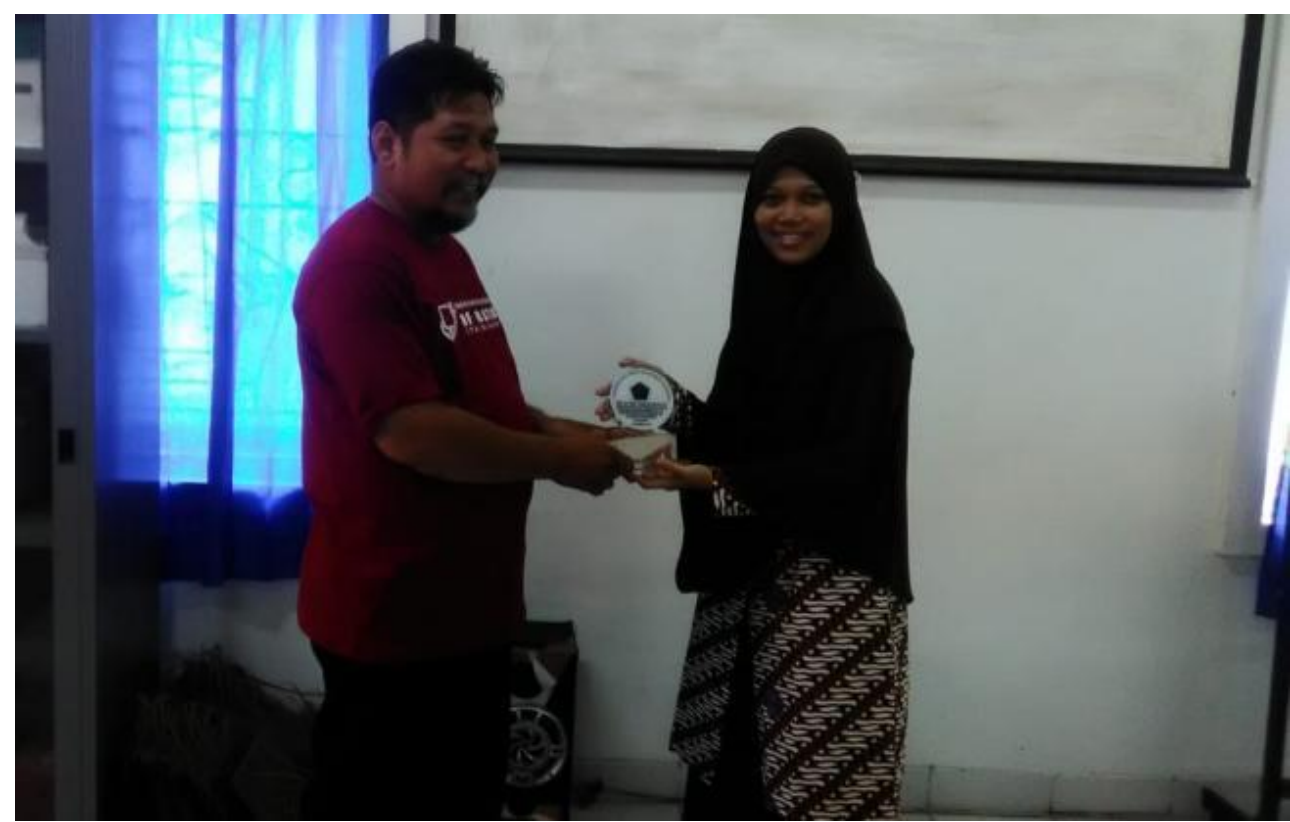

Gambar 4. Pemberian Kenang-Kenangan dari Departemen Informatika STTA kepada UP2K PKK Kelurahan Prawirodirjan

Kegiatan dalam pembuatan profil produk lebih dikhususkan dalam pemanfaatan media kamera handphone dalam mengambil gambar untuk pembuatan foto profil produk dan jasa yang akan dipasarkan, sehingga akan menampilkan hasil yang didapatkan dapat terlihat menarik dimedia online. 
Tabel 1. Hasil penilaian terhadap cara pengoperasian kamera handphone

\begin{tabular}{|c|c|c|c|c|}
\hline \multirow{2}{*}{ No. } & \multirow{2}{*}{ Nama } & \multicolumn{3}{|c|}{ Hasil Penilaian } \\
\hline & & Kurang & Cukup & Baik \\
\hline 1 & Bapak Rusdi Haryanto & & & $\sqrt{1}$ \\
\hline 2 & Bapak. Ajar Permono & & & $\sqrt{ }$ \\
\hline 3 & Ibu Sri Lestari & & & $\sqrt{ }$ \\
\hline 4 & Ibu Isti Faijah & & & $\sqrt{ }$ \\
\hline 5 & Ibu Kuswati & & & $\sqrt{ }$ \\
\hline 6 & Ibu Baridjatin $S$ & & & $\sqrt{ }$ \\
\hline 7 & Ibu Issrimaryatun & & & $\sqrt{ }$ \\
\hline 8 & Ibu Herni Indrawati & & & $\sqrt{ }$ \\
\hline 9 & Ibu Siti Partiwi & & & $\sqrt{ }$ \\
\hline 10 & Ibu Herniwati & & & $\sqrt{ }$ \\
\hline 11 & Ibu C. Sumiyati & & & $\sqrt{ }$ \\
\hline 12 & Ibu Endang Banowati & & & $\sqrt{ }$ \\
\hline 13 & Ibu Eny Purwatiningsih & & & $\sqrt{ }$ \\
\hline 14 & Ibu Sri Ningsih & & $\sqrt{ }$ & \\
\hline 15 & Ibu Th. Gesang Sri A & & & $\sqrt{ }$ \\
\hline 16 & Ibu N. Subagyo & & & $\sqrt{ }$ \\
\hline 17 & lbu Erna Supartinah & & $\sqrt{ }$ & \\
\hline 18 & Ibu Susi Parwati & & $\sqrt{ }$ & \\
\hline 19 & Ibu Sumaryati & & & $\sqrt{ }$ \\
\hline 20 & Ibu Agustin & & & $\sqrt{ }$ \\
\hline 21 & Ibu Betharinawati & & & $\sqrt{ }$ \\
\hline 22 & Ibu Sutini & & $\sqrt{ }$ & \\
\hline 23 & Ibu Budi Artini & & & $\sqrt{ }$ \\
\hline 24 & Ibu Ria Kartini & & & $\sqrt{ }$ \\
\hline 25 & Ibu Sumarti & & & $\sqrt{ }$ \\
\hline 26 & Ibu Rahayu Mulyo S. & & & $\sqrt{ }$ \\
\hline 27 & Ibu Tri Mulyani & & & $\sqrt{ }$ \\
\hline 28 & Ibu Kristin Puspandari & & & $\sqrt{ }$ \\
\hline
\end{tabular}

Sebelumnya pelaku usaha diberikan informasi fitur kamera handphone yang telah dimiliki sehingga dapat digunakan secara maksimal, karena sebagian besar pelaku usaha belum paham cara pengoperasian kamera di handphone. Dari hasil Tabel 1 diketahui dari 28 orang $85.7 \%$ mampu mengoperasikan kamera handphone dengan baik dan 14,3\% cukup mengerti pengoperasian kamera yang ada di handphone.

Selanjutnya dalam pengambilan foto produk diajarkan beberapa teknik fotografi yang sederhana seperti sudut pandang kamera atau angel misal pengambilan foto dari sisi atas, samping, depan dan bawah, juga diajarkan sedikit tentang pencahayaan agar produk terlihat lebih jelas. Hasil mengambil foto dengan sudut pandang yang berbeda dapat dilihat pada Gambar 5 s.d 8. 


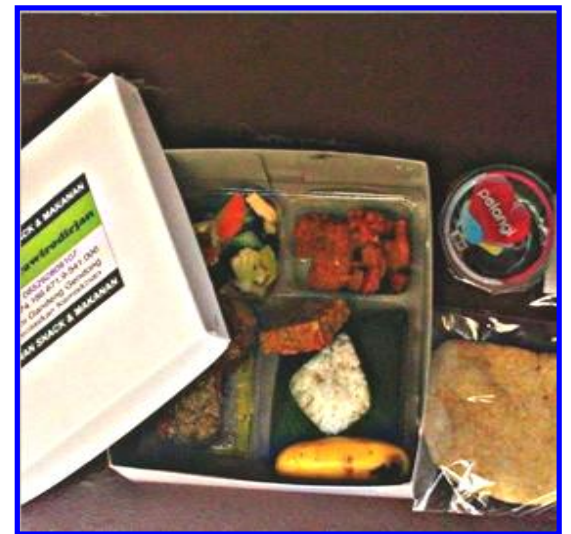

(a)

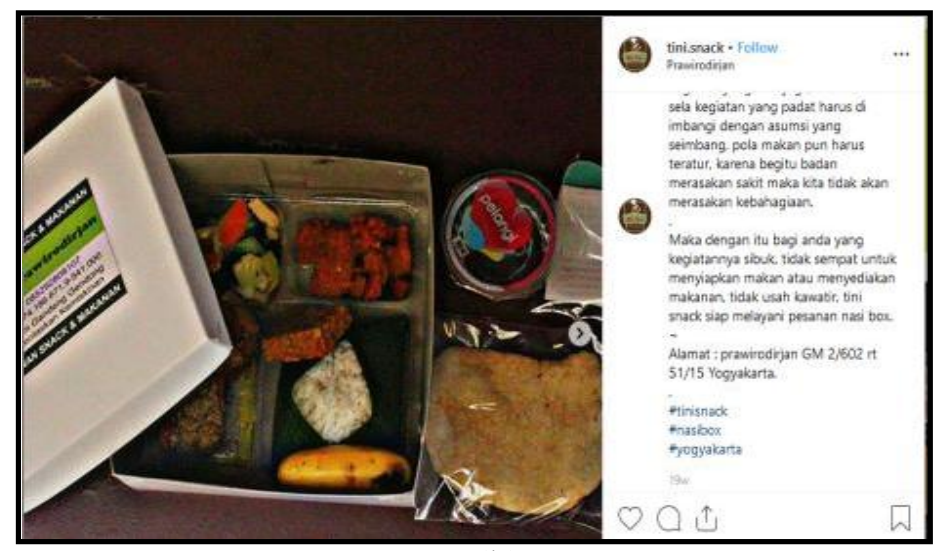

(b)

Gambar 5. (a) Pengambilan foto profil produk nasi box dari sisi atas dengan pencahayaan dari samping (b) Foto produk nasi box ditampilkan di media online

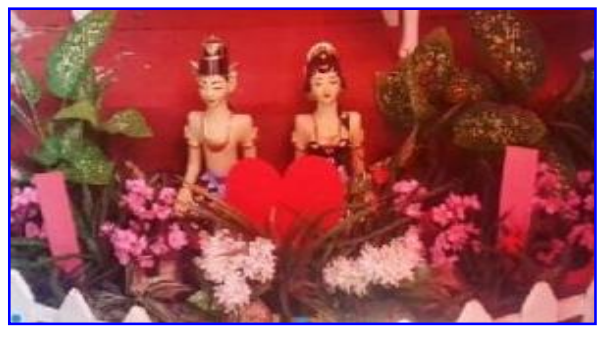

(a)

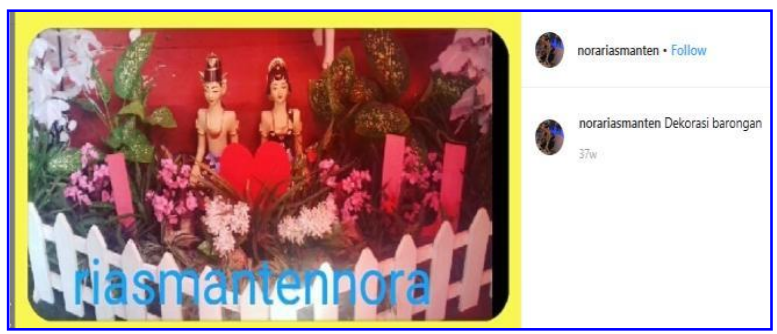

(b)

Gambar 6. (a) Pengambilan foto profil jasa rias panggung pengantin dari sisi depan dengan pencahayaan dari depan (b) Foto produk jasa rias panggung pengantin ditampilkan di media online

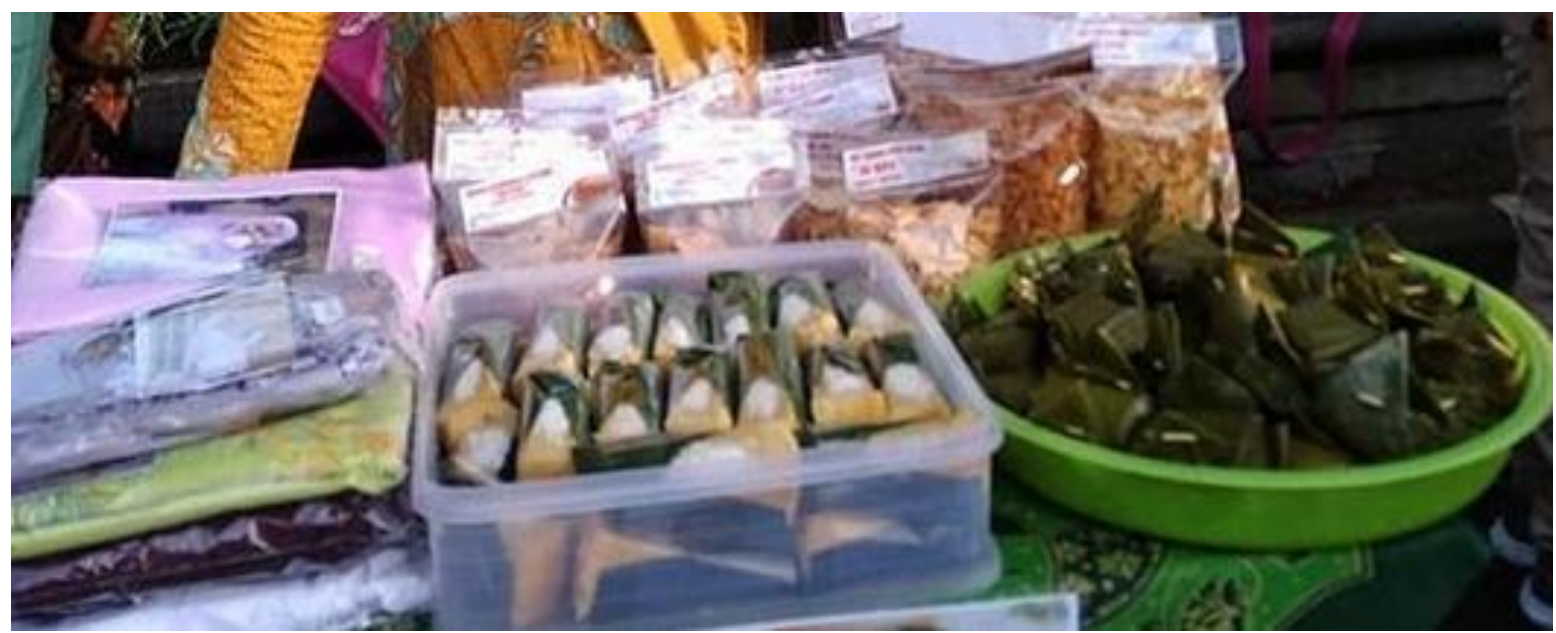

Gambar 7. Pengambilan foto profil jajanan pasar dengan memanfaatkan cahaya alami diluar ruangan

Pencahayaan, penambahan ornamen lainnya dan penyusunan materi produk juga sangat berpengaruh dalam menghasilkan tampilan objek yang lebih menarik seperti pada Gambar 8. 


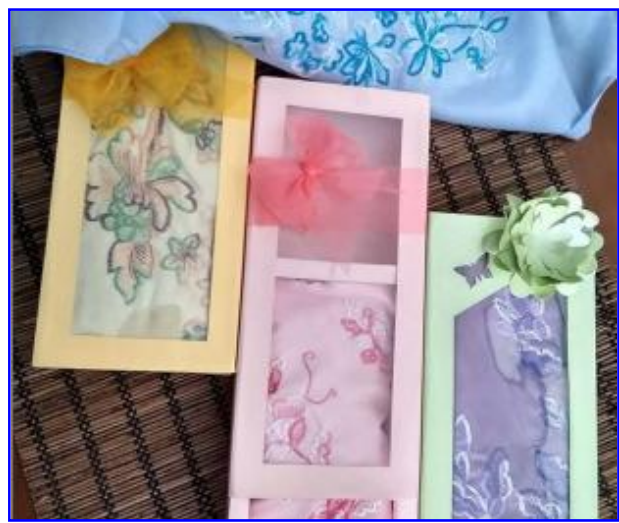

(a)

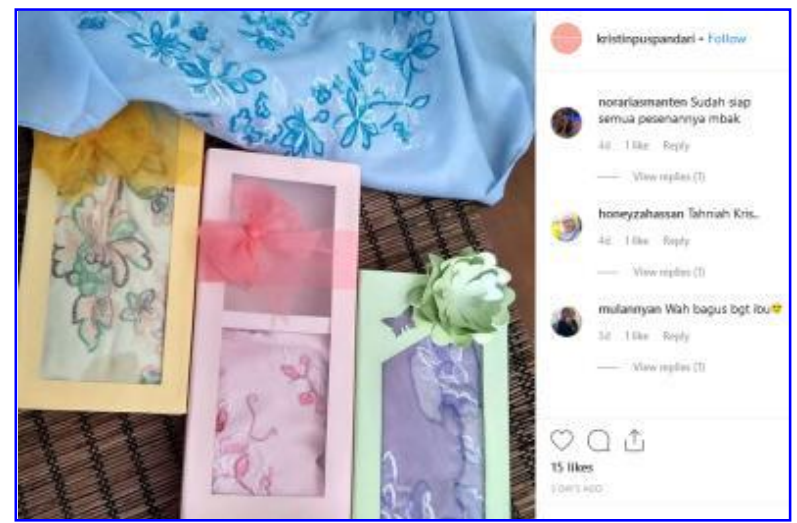

(b)

Gambar 8. (a) Pengambilan foto profil produk hijab dari sisi atas dengan pencahayaan dari samping atas dengan penambahan ornamen tambahan (b) Foto produk hijab ditampilkan di media online

Tabel 2. Hasil penilaian terhadap pencahayaan dan angel foto

\begin{tabular}{|c|c|c|c|c|}
\hline \multirow{2}{*}{ No. } & \multirow{2}{*}{ Nama } & \multicolumn{3}{|c|}{ Hasil Penilaian } \\
\hline & & Kurang & Cukup & Baik \\
\hline 1 & Bapak Rusdi Haryanto & & & $\sqrt{1}$ \\
\hline 2 & Bapak. Ajar Permono & & & $\sqrt{ }$ \\
\hline 3 & Ibu Sri Lestari & & & $\sqrt{ }$ \\
\hline 4 & Ibu Isti Faijah & & & $\sqrt{ }$ \\
\hline 5 & Ibu Kuswati & & & $\sqrt{ }$ \\
\hline 6 & Ibu Baridjatin $\mathrm{S}$ & & & $\sqrt{ }$ \\
\hline 7 & Ibu Issrimaryatun & & $\sqrt{ }$ & \\
\hline 8 & Ibu Herni Indrawati & & & $\sqrt{ }$ \\
\hline 9 & Ibu Siti Partiwi & & & $\sqrt{ }$ \\
\hline 10 & Ibu Herniwati & & & $\sqrt{ }$ \\
\hline 11 & Ibu C. Sumiyati & & $\sqrt{ }$ & $\sqrt{ }$ \\
\hline 12 & Ibu Endang Banowati & & & $\sqrt{ }$ \\
\hline 13 & Ibu Eny Purwatiningsih & & & $\sqrt{ }$ \\
\hline 14 & Ibu Sri Ningsih & & $\sqrt{ }$ & \\
\hline 15 & Ibu Th. Gesang Sri A & & & $\sqrt{ }$ \\
\hline 16 & Ibu N. Subagyo & & & $\sqrt{ }$ \\
\hline 17 & lbu Erna Supartinah & & $\sqrt{ }$ & \\
\hline 18 & Ibu Susi Parwati & & $\sqrt{ }$ & \\
\hline 19 & Ibu Sumaryati & & & $\sqrt{ }$ \\
\hline 20 & Ibu Agustin & & & $\sqrt{ }$ \\
\hline 21 & Ibu Betharinawati & & & $\sqrt{ }$ \\
\hline 22 & Ibu Sutini & & $\sqrt{ }$ & \\
\hline 23 & Ibu Budi Artini & & & $\sqrt{ }$ \\
\hline 24 & Ibu Ria Kartini & & & $\sqrt{ }$ \\
\hline 25 & Ibu Sumarti & & & $\sqrt{ }$ \\
\hline
\end{tabular}


Ibu Rahayu Mulyo S.

27 Ibu Tri Mulyani

28 Ibu Kristin Puspandari

Tabel 2. Merupakan hasil pengujian terhadap pemahaman para pelaku usaha terhadap teknik fotografi dengan memanfaatkan kamera handphone dengan mempraktekkan pengambilan foto profil produk dari berbagai posisi/angel dan pemanfaatan cahaya alami dari berbagai posisi. Hasil yang ditunjukkan dari Tabel 2 menunjukkan $71.5 \%$ para pelaku usah mampu dengan baik mengambil foto produk dari berbagai posisi dan mengatur pola pencahayaan yang diinginkan, sedangkan 28,5 $\%$ para pelaku usaha sudah dapat melakukan pengambilan foto produk dengan cukup baik tetapi mengalami kesulitan memahami pola pencahayaan.

\section{Kesimpulan}

Kegiatan pengabdian kepada masyarakat berupa pendampingan pelatihan pembuatan profil produk untuk pemasaran produk melalui online bagi pelaku UP2KPKK Prawirodirjan yang diselenggarakan oleh Dosen Departemen Informatika STTA Yogyakarta mampu memberikan kontribusi positif terhadap peningkatan kemampuan serta kreativitas para peserta dalam pembuatan profil produk, khususnya untuk pengambilan foto atau video dan pengeditannya. Untuk ke depannya perlu dikembangkan lagi ketrampilan dalam pembuatan profil produk seperti foto dan video produk memanfaatkan beberapa aplikasi.

\section{Daftar Pustaka}

[1] Gusfrianti, R., \& Budiartiningsih, R. (2010). Peranan Program Usaha Peningkatan Pendapatan Keluarga (UP2K) terhadap Peningkatan Pendapatan Keluarga di Kecamatan Cerenti Kabupaten Kuantan Singingi. Jurnal Ekonomi Universitas Riau, 18(04).

[2] Prastyo, N. A. (2012). Pembuatan Video Profil Tiga Dimensi (3D) Sentra Ponsel Kudus. Speed-Sentra Penelitian Engineering dan Edukasi, 2(4).

[3] Jawab, P., \& Penyusun, T. Panduan Penelitian Dan Pengabdian Kepada Masyarakat Edisi XII Tahun 2018.

[4] Ayuningtyas, A., Honggowibowo, A. S., Pujiastuti, A., Retnowati, N. D., \& Indrianingsih, Y. (2018). Pendampingan Pembuatan Bahan Ajar Bagi Guru Sekolah Dasar Islam Terpadu (SDIT) Salsabila Al Muthi'in Berbasis Multimedia dengan Menggunakan Microsoft Power Point. KACANEGARA Jurnal Pengabdian pada Masyarakat, 1(1), 1-6.

[5] Nugraheny, D., Wintolo, H., \& Kusumaningrum, A. (2018). Pendampingan Pembuatan Bahan Ajar Berbasis Multimedia Menggunakan Macromedia Flash Bagi Para Guru SD IT Salsabila Al Muthi'in, Yogyakarta. KACANEGARA Jurnal Pengabdian pada Masyarakat, 1(1), 23-28.

[6] Ayuningtyas, A., Retnowati, N. D., Pujiastuti, A., Indrianingsih, Y., \& Honggowibowo, A. S. (2019). Pelatihan Mendesain Artikel Artistik Menggunakan Microsoft Word Bagi Kelas 5 SD di SDIT Salsabila Al Muthi' in Yogyakarta. KACANEGARA Jurnal Pengabdian pada Masyarakat, 2(1), 13-20.

[7] Nugraheny, D., Wintolo, H., Kusumaningrum, A., Sudaryanto, S., \& Sajati, H. (2019). Pendampingan Pengenalan Metode Pengetikan Cepat Menggunakan Microsoft Word Bagi Siswa Kelas 5 SD IT Salsabila Al Muthi'in Yogyakarta. KACANEGARA Jurnal Pengabdian pada Masyarakat, 2(1), 21-28. 
Harliyus Agustian, Asih Pujiastuti, Astika Ayuningtyas, Anton Setiawan Honggowibowo, Yuliani...

[8] Indika, D. R., \& Jovita, C. (2017). Media sosial instagram sebagai sarana promosi untuk meningkatkan minat beli konsumen. Jurnal Bisnis Terapan, 1(01), 25-32.

[9] Arief, G. M., \& Millanyani, H. (2015). Pengaruh Social Media Marketing Melalui Instagram Terhadap Minat Beli Konsumen Sugar Tribe. eProceedings of Management, 2(3).

[10] Gumilar, G. (2016). Pemanfaatan instagram sebagai sarana promosi oleh pengelola industri kreatif fashion di kota Bandung. JIPSI-Jurnal Ilmu Politik dan Komunikasi UNIKOM, 5(2). 